\title{
Performance and cost characteristics of multi-electron transfer, common ion exchange non-aqueous redox flow batteries
}

\author{
Sydney M. Laramie ${ }^{a, b, \dagger}$, Jarrod D. Milshtein ${ }^{a, c, \dagger}$, Tanya M.Breault ${ }^{a, b}$, \\ Fikile R. Brushett ${ }^{\mathrm{a}, \mathrm{d}}$, Levi T.Thompson ${ }^{\mathrm{a}, \mathrm{b}^{*}}$ \\ a Joint Center for Energy Storage Research, USA \\ ${ }^{b}$ Department of Chemical Engineering, University of Michigan, 2300 Hayward St.,Ann Arbor, MI 48109, USA \\ ${ }^{c}$ Department of Materials Science and Engineering, Massachusetts Institute of Technology, 77 Massachusetts Ave., \\ Cambridge, MA 02139, USA \\ ${ }^{d}$ Department of Chemical Engineering, Massachusetts Institute of Technology, 77 Massachusetts Ave., Cambridge, MA \\ 02139, USA
}

\begin{abstract}
Non-aqueous redox flow batteries (NAqRFBs) have recently received considerable attention as promisinghigh energy density,low cost grid-level energy storage technologies. Despite these attractive features,NAqRFBsare still at an early stage of development and innovative designtechniques are necessary to improve performance and decrease costs. In this work, we investigate multi-electron transfer, commonion exchangeNAqRFBs. Common ion systemsdecrease thesupporting electrolyte requirement, which subsequently improves active material solubility and decreases electrolytecost.Voltammetric and electrolytic techniques are used to study the electrochemical performance and chemical compatibility of model redox active materials, iron (II) tris(2,2'-bypridine) tetrafluoroborate(Fe(bpy $\left.)_{3}\left(\mathrm{BF}_{4}\right)_{2}\right)$ and ferrocenylmethyl dimethyl ethyl ammonium tetrafluoroborate $\left(\mathrm{Fc1N112-BF}{ }_{4}\right)$. These results helpdisentangle complex cycling behavior observed in flow cell experiments.Further, a simple techno-economic modeldemonstrates the cost benefits of employing common ion exchange NAqRFBs, afforded by decreasing the salt and solventcontributions to total chemical cost.This study highlights two new concepts, common ion exchange and multi-electron transfer, for NAqRFBs through a demonstration flow cell employing model active species. In addition, the compatibility analysis developed for asymmetric chemistries can apply to other promising species, including organics, metal coordination complexes (MCCs) and mixed MCC/organic systems, enabling the design of low cost NAqRFBs.
\end{abstract}

\footnotetext{
${ }_{*}^{\dagger}$ Equal contributions

* Corresponding author. Tel. +17349362015

Email address: Itt@umich.edu (L. Thompson)
} 
Keywords: non-aqueous redox flow battery;metal coordination complex; multielectron;common ion;rocking chair;energy storage 


\section{Introduction}

The push to increase utilization of renewable energy sources is driving the development of grid-level energy storage devices to offset the intermittency of wind and solar. [1]Energy storage can also provide load-leveling benefits to increase the efficiency of current natural gas and coal-fired power plants.[2]Redox flow batteries (RFBs) offer an attractive solution to thegrid-level energy storage problem. RFBs decouple capacity and power, allowing for increased adaptability, while also offering long lifetimes, facile thermal management, and no geographical limitations.[3]State of the art RFB chemistries, however, are too expensive for widespread implementation. The DOE Office of Electricity Delivery and Energy Reliability set a target priceof $\$ 150 \mathrm{kWh}^{-1}$, including installation and inverter costs, to achieve full integration of an energy storage system thatprovides $4 \mathrm{~h}$ of storage. [4]Estimated system prices for RFBsin 2014, excluding installation costs, exceeded $\$ 500 \mathrm{kWh}^{-1}$. [5,6]Although these estimates are well above the desired price, a recent techno-economic assessment indicated that pathways exist for both aqueous (Aq) and non-aqueous (NAq) RFBs to meet the aggressivetarget. [5]Non-aqueous systems in particular offer a number of advantages over their aqueous counterparts. First, non-aqueous solvents provide electrochemical windows that can exceed $4 \mathrm{~V}$, more than triple the thermodynamic electrochemical window (1.23 V) accessible in water, [7] allowing for high energy density RFBs and facilitating the use of multiple redox couples. [3]Second, arange of solvents and supporting salts are available to optimize system performance. Third, a wide array of active species is available, and through functionalization, target driven iterations can tune the electrochemical and physicochemical properties of the active species. [3,8]

Recent efforts to increase the energy density and decrease the cost of NAqRFBshave focused onimproving active species solubility via molecular modifications[8-10] and developingactive species with low molecular weights.[11,12]The development of common ion exchange systems is an additional consideration that will aid indesigning economicallyviableNAqRFBs. In a common ion exchange NAqRFB, both active species havecharges of the same sign, either positive or negative, and as a result,only a single ion of the supporting salt migrates across the separator as a charge carrier.Equations 1 and 2 show the full cell reactions for cation and anion exchange systems, respectively.

$$
\mathrm{A}^{n+}+\mathrm{B}^{(n+1)+} \leftrightarrow \mathrm{A}^{(\mathrm{n}+1)+}+\mathrm{B}^{n+}
$$




$$
\mathrm{A}^{(n+1)-}+\mathrm{B}^{n-} \leftrightarrow \mathrm{A}^{\mathrm{n}-}+\mathrm{B}^{(n+1)-}
$$

In both cases, $A$ is the positive redox active compound, $B$ is the negative redox active compound, and $n$ is an integer greater than or equal to zero. Utilizing active species with similar charges eliminates the salt splittingthat occurs in non-common ion exchange systems.Figure 1a schematically illustrates salt splitting RFB redox reactions. Note that to maintain bulk electroneutrality, supporting salt anions migrate to the positive electrolyte (posolyte), and supporting salt cations migrate to the negative electrolyte (negolyte).In this configuration, the supporting salt ions are critical reactants in the redox processes and could limit RFB capacity.

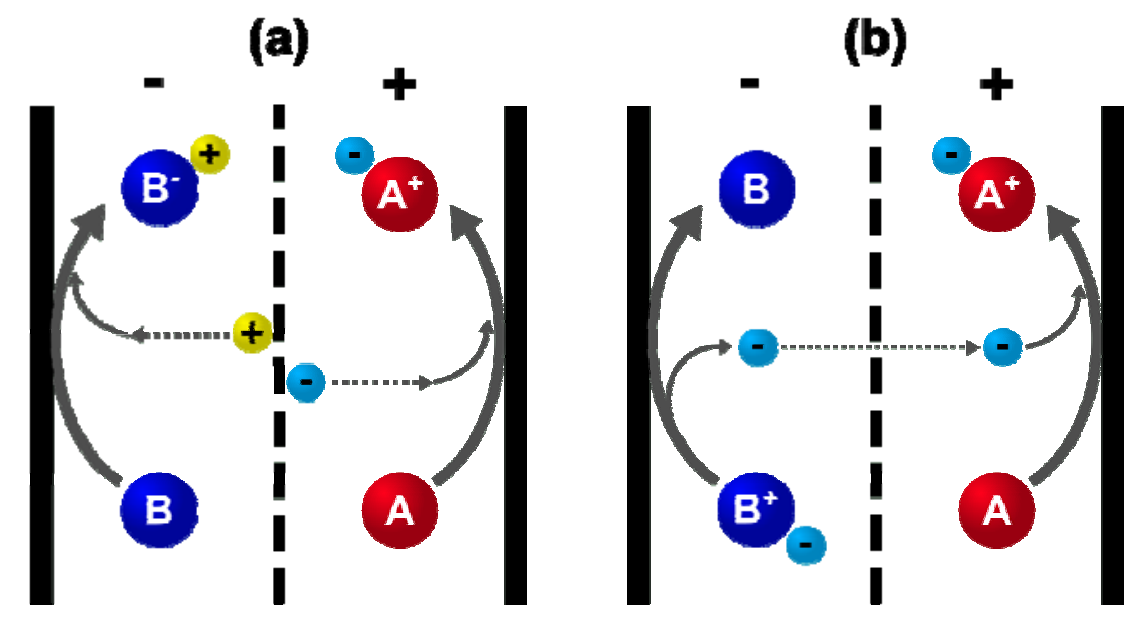

Figure 1: Schematiccomparison of charging processes in (a)a salt splitting RFBand (b)a common anion exchange RFB. A is the posolyte active material (red), and $B$ is the negolyte active material (dark blue). Supporting salt cations are denoted by "+" (yellow), and supporting salt anions are denoted by "-" (light blue).

Figure 1 billustrates common anion exchange redox events, where only supporting salt anions carry charge across the membrane or separator. This configuration resembles a "rocking chair" lithium ion battery. [13]From an economic perspective, common ion exchange systems are advantageous as they reduce the required amount ofexpensive supporting salt $\left(\geq \$ 20 \mathrm{~kg}^{-1}\right.$ for NAqRFBs[5,14,15]). Fora salt splitting configuration, the electrolyte must dissolve enough supporting salt to maintain bulk electroneutrality in the presence of the charged active species (Figure 1a). In contrast, for the common ion exchange configuration, the saltonly serves to enhance electrolyte conductivity.High concentrations of salt can limit the solubility of the active species in the electrolyte solution[16,17] and suppress the conductivity of ionselective membranes, subsequently increasing the area specific resistance (ASR).[18]Overall, common ion 
exchange enables higher active species concentrations, increasing electrolyte energy density, and minimizing the use of expensive NAq solvents.

To date, many reported NAqRFBs employ a salt splitting configuration. [19-22] A notable example is the vanadium acetylacetonate $\left(\mathrm{V}(\mathrm{acac})_{3}\right) \mathrm{NAqRFB}$, where, upon charging, an anion is formed inthe negolyte $\left(\mathrm{V}(\mathrm{acac})_{3}{ }^{-}\right)$, while a cation is generatedin the posolyte $\left(\mathrm{V}(\mathrm{acac})_{3}{ }^{+}\right) \cdot[16]$ Some studies report the use of common ion exchangefor NAqRFBs, but do not contemplate the cost and performance benefits of employing this configuration. The majority of theseprior reports describe symmetric common anion exchange systems utilizing tris-bipyridine metal coordination complexes, includingchromium, iron, and rutheniumtris-bipyridines.[23-25]A fewasymmetric anion exchange systemsutilized two tris-bipyridine complexes with different metal centers.[2628]A vanadium dithiolate complex was the focus of the only symmetric common cation exchange system. [29] Of these,only onereport demonstrateda $2 e^{-}$transfer system, which utilizedaCr(bpy $)_{3}$ derivative in a symmetric, $2 \mathrm{e}^{-} \mathrm{H}$-cell, but that studydid not cycle the active species ina full flow cell. [25]

This paper is the first to purposefully designand demonstrate the benefits of common ion exchange NAqRFBs.Iron (II) tris(2,2'-bypridine) tetrafluoroborate $\left(\mathrm{Fe}(\mathrm{bpy})_{3}\left(\mathrm{BF}_{4}\right)_{2}\right)$ and ferrocenylmethyl dimethyl ethyl ammonium tetrafluoroborate (Fc1N112-BF 4$)$ serveas model active species (Figure S1), and are examined viaa progression of electrochemicaltechniques.First, cyclic voltammetry (CV) and bulk electrolysis of both the individual species and the mixturehighlight the compatibility and stability of each redox event. Small volume $\mathrm{H}$-type cells with reference electrodes evaluatecell performance while confirming that the cell accesses the desired redox events. As a final analysis, flow cell studies demonstrate the practicality of common ion exchange RFBs, as well as the complexity of multi-electron transfer systems.Flow cell cycling experiments characterize both the one electron $\left(1 \mathrm{e}^{-}\right)$and, for the first time, two electron $\left(2 \mathrm{e}^{-}\right)$variations of the $\mathrm{Fe}(\mathrm{bpy})_{3}\left(\mathrm{BF}_{4}\right)_{2} / \mathrm{Fc} 1 \mathrm{~N} 112-\mathrm{BF}_{4}$ system. A techno-economic model quantifies the financial benefits of common ion exchange systems. Taken as a whole, this work develops an extensive compatibility analysis of asymmetric NAqRFB chemistries. The systematic approach and suite of electrochemical techniquesutilizedhere can apply to other promising active species, including organics, metal coordination complexes (MCCs), and mixed MCC/organic systems, enabling asymmetric NAqRFBsthat approach the DOE price target. 


\section{Experimental}

\subsection{Syntheses and Materials}

All reagents and starting materials(iron(II) tetrafluoroborate hexahydrate (97\%), (dimethylaminomethyl)ferrocene (96\%), bromoethane (98\%), sodiumtetrafluoroborate $(98 \%))$ for active species synthesis were purchased from Sigma-Aldrich, with the exception of 2,2'-bipyridine (98\%, Alfa Aesar). All synthesis materialswere used as received. $\mathrm{Fe}(\mathrm{bpy})_{3}\left(\mathrm{BF}_{4}\right)_{2}$ was prepared according to a literature procedure.[30]Fc1N112$\mathrm{BF}_{4}$ was synthesizedthrough a bromide salt intermediate also as reported in literature.[31] lon exchange of $\mathrm{Br}^{-}$with $\mathrm{BF}_{4}^{-}$was performed in deionized water to afford the final product.All electrochemical experiments were performed in acetonitrile (MeCN, $99.9 \%$, Acros Organics), which was stored over molecular sieves to remove any residual water. Electrochemical grade tetrabutylammoniumtetrafluoroborate $\left(\mathrm{TBABF}_{4}, 99 \%\right.$, Sigma Aldrich) wasdried under vacuum at $80^{\circ} \mathrm{C}$ overnight before use.Fritted $\mathrm{Ag} / \mathrm{Ag}^{+}$ quasi-reference electrodes (BASi) filled with $0.01 \mathrm{M}$ silver tetrafluoroborate (98\%, Sigma Aldrich) in $\mathrm{MeCN}$ were used. All solution preparation and electrochemical measurements were performed inside argon filled glove boxes $\left(\mathrm{O}_{2}<5 \mathrm{ppm}, \mathrm{H}_{2} \mathrm{O}<1 \mathrm{ppm}\right)$. Daramic 175 microporous separator, with a thickness of $175 \mu \mathrm{m}$, porosity of $58 \%$, and average pore size of $100 \mathrm{~nm}$, was employed as received during battery cycling experiments.

\subsection{Solubility measurements}

Active material solubility measurements were performed using a UV-Vis method [9] in both pure solvent and in the presence of supporting salt. First, stock solutions of $\mathrm{Fe}(\mathrm{bpy})_{3}\left(\mathrm{BF}_{4}\right)_{2}$ or $\mathrm{Fc} 1 \mathrm{~N} 112-\mathrm{BF}_{4}$ were prepared at known concentrations in MeCN. Fivepoint calibration curves of characteristic absorbance peaks as a function of active species concentration were established. The individual active species wereadded in excess to pure $\mathrm{MeCN}$ or $0.5 \mathrm{M} \mathrm{TBABF}_{4} / \mathrm{MeCN}$ to generate solutions saturated with the active material. The saturated solutions were centrifuged at $6000 \mathrm{rpm}$ for $5 \mathrm{~min}$. The supernatant was diluted with $\mathrm{MeCN}$ or $0.5 \mathrm{M} \mathrm{TBABF}_{4} / \mathrm{MeCN}$ to within the range of the absorption calibration curve, and the absorption of the diluted solution was measured using UV-Vis (Figure S2). Given the difficulty of measuring solubility in ternary electrolytes, it was assumed that $\mathrm{TBABF}_{4}$ did not precipitate out of solution due to the high solubility limit of $\mathrm{TBABF}_{4}$ in $\mathrm{MeCN}$ (> $3 \mathrm{M}$ ). [32] 


\subsection{Cyclic voltammetry}

Cyclic voltammetry was performed using an Autolab PGSTAT100 potentiostat.CVs were recorded at a scan rate of $100 \mathrm{mVs}^{-1}$ in a custom $10 \mathrm{mLthree}$ electrode electrochemical cell with a $3 \mathrm{~mm}$ diameter glassy carbon (GC) working electrode (BASi), a coiled platinum $(\mathrm{Pt})$ wire counter, and $\mathrm{Ag} / \mathrm{Ag}^{+}$quasi-reference electrode. All solutions contained $0.5 \mathrm{M} \mathrm{TBABF}_{4} / \mathrm{MeCN}$ with either $5 \mathrm{mM}$ of the individual active species or an equi-molar mixture containing $5 \mathrm{mM}$ of both $\mathrm{Fe}(\mathrm{bpy})_{3}\left(\mathrm{BF}_{4}\right)_{2}$ and $\mathrm{Fc} 1 \mathrm{~N} 112-\mathrm{BF}_{4}(10 \mathrm{mM}$ total).

\subsection{Bulk electrolysis}

Bulk electrolysis experiments were performed in a custom glass $\mathrm{H}$-type cell (Figure S3) comprised of two5 $\mathrm{mL}$ chambers separated with an ultra-fine glass frit (P5, Adams and Chittenden) to minimize crossover. Both chambers were stirred continuously during cycling. Reticulated vitreous carbon (100 PPI, Duocell) was used as the working electrode with a Pt coil counter electrode and $\mathrm{Ag} / \mathrm{Ag}^{+}$quasi-reference electrode. AnAutolab PGSTAT100 potentiostat was used to apply a constant current, $1.32 \mathrm{~mA}$, which is equivalent to a C-rate of $2 \mathrm{C}$. Potential cutoffs and a $100 \%$ SOC coulombic cutoff were used during cycling. $\mathrm{A} 3 \mathrm{~mm}$ diameterGCworking electrode (BASi) was used to record CVs before and during cycling. Solutions of $5 \mathrm{mM}$ active species in $0.5 \mathrm{M}$ $\mathrm{TBABF}_{4} / \mathrm{MeCN}$ were used for the single species experiments and for the mixed species tests; $5 \mathrm{mM}$ of both active species (10 mM total) were dissolved in $0.5 \mathrm{M} \mathrm{TBABF} / \mathrm{MeCN}$.

\subsection{H-cell cycling}

Glass $\mathrm{H}$-type cells (Adams and Chittenden) requiring $5 \mathrm{~mL}$ of solution in each chamber, with an inter-electrode distance of $5 \mathrm{~cm}$, were used for the $\mathrm{H}$-cell experiments. Graphite electrodes $\left(3.6 \mathrm{~cm}^{2}\right.$, iso-molded, ground finish, Graphite Store) were heat treated at $500^{\circ} \mathrm{C}$ for $5 \mathrm{~h}$ under argon before use.Quasi-reference electrodes were inserted into the posolyte and negolyte chambers to monitor the potential of each halfcellduring cycling. Daramic $175\left(1.3 \mathrm{~cm}^{2}\right)$ was employed as the separator. To reduce crossover, two layers were stacked together in the cell. Cycling experiments were performed using a Maccor 4000 Series Battery Tester at a constant C-rate of C/2 (0.95 $\mathrm{mAcm}^{-2}$ ) to $100 \%$ SOC, with negolyte and posolytecutoffs based on CV potentials. All cells used asolution of0.5 $\mathrm{M} \mathrm{TBABF}_{4} / \mathrm{MeCN}$ with $50 \mathrm{mM}$ of bothFe $(\mathrm{bpy})_{3}\left(\mathrm{BF}_{4}\right)_{2}$ and Fc1N112-BF 4 as the negolyte and posolyte. 


\subsection{Flow cell cycling}

Custom cells with flow through electrodes (Figure S4), similar to those employed by Wei et al. [8,33], were used forflow cell cycling experiments. The flow channels and current collectors were machined from type 316 stainless steel. Electrodes were cut from $6 \mathrm{~mm}$ thick carbon felt (GFA6, SGL Group) and compressed by $12.4 \%$ in the assembled flow cell, providing a geometric active area of $4.63 \mathrm{~cm}^{2}$. Two layers of Daramic 175 separator were stacked together to serve as the battery separator. Teflon gaskets sealed the separator into the cell. All flow cells were initially assembled outside the glove box, and were then dried under vacuum $\left(-91 \mathrm{kPa}_{\mathrm{g}}\right)$ at room temperature for at least $1 \mathrm{~h}$ before beginning flow cell experiments.

Glass scintillation vials were filled with electrolyte, which was carried into the flow cell

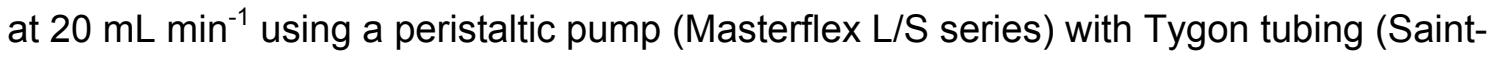
Gobain, $1.6 \mathrm{~mm}$ inner diameter). Galvanostatic cycling experiments were performed using a Biologic-VMP3 potentiostat at a constant current density of $5 \mathrm{~mA} \mathrm{~cm}{ }^{-2}(23.2$ $\mathrm{mA})$.Electrolytes were comprised of $0.1 \mathrm{M} \mathrm{Fe}(\mathrm{bpy})_{3}\left(\mathrm{BF}_{4}\right)_{2} / 0.1 \mathrm{M} \mathrm{Fc} 1 \mathrm{~N} 112-\mathrm{BF}_{4} / 0.5 \mathrm{M}$ $\mathrm{TBABF}_{4} / \mathrm{MeCN}$. $10 \mathrm{~mL}$ of electrolyte was added to each of the two flow cell reservoirs. During the cycling experiments, cell potential cutoffs were $1.0-2.01 \mathrm{~V}$ and $1.0-2.45 \mathrm{~V}$ for the $1 \mathrm{e}$ - and $2 \mathrm{e}^{-}$cells, respectively. Upper voltage cutoffs were selected to eliminate accessing undesired electrochemical reactions, while lower voltage cutoffs were selected to ensure complete discharge of the cells.

\section{Results \& Discussion}

\subsection{Active Species and Separator Selection}

Several criteria aid the selection of electrochemical couples forthe common ion exchange NAqRFB. The first, and most important, criterionisto exhibit multiple electron transfers, which should result in significant energy density gains. Second, the active species have to be soluble and stable in the same solvent at all relevantoxidation states. Third, the active species need to be commercially available or easy to synthesize in large quantities,facilitating use in a lab-scale flow cell. Based on these considerations, $\mathrm{Fe}(\mathrm{bpy})_{3}\left(\mathrm{BF}_{4}\right)_{2}$ was selected as the low potential active material and $\mathrm{Fc} 1 \mathrm{~N} 112-\mathrm{BF}_{4}$ as the high potential active material. $\mathrm{Fe}(\mathrm{bpy})_{3}\left(\mathrm{BF}_{4}\right)_{2}$ exhibits four redox events [34] and has 
moderate solubility in MeCN.Although $\mathrm{Fe}(\mathrm{bpy})_{3}\left(\mathrm{BF}_{4}\right)_{2}$ undergoes relatively quick capacity fade, this active material is one of only a few rigorously characterizedcationic negolyteNAqRFB species,[24] and thus is suitable for the demonstration of a common ion cell over relatively short cycling experiments. The redox active Fc1N112 ${ }^{+}$ cationisanattractive posolyte material due to its electrochemical stability and high

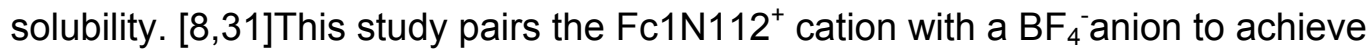
common ion exchange. [31] Designing an asymmetric system enables independent selection of the negolyte and posolyte materials to achieve desirable properties for both sides. Due to the limited selectivity of available NAqRFB membranes and separators $[18,35]$,active species mixing in an asymmetric NAqRFB is presently unavoidable. Imminent active species crossovermotivatedour active species compatibility studies.Further, anion exchange membranesexhibit limited stability in non-aqueous solvents.[26,35]Thus, full cells (H-cell and flow) in this study employ a stable Daramic separator to minimize interactions between the separator and the active species and eliminate separator degradation as a performance decay mechanism.

\subsection{Solubility}

As previously mentioned, a key advantage associated withcommon ion exchange NAqRFBs is the ability to minimize the quantity of supporting salt required for RFB operation.Minimizing the salt content enables reduced solvent costs (Section 3.5) and higher active materials concentrations, which can subsequently decrease concentration (mass transport) and activation (kinetic) polarization losses.[36]Shinkle et al. reported that the solubility of $(\text { (acac) })_{3}$ in MeCNdecreased monotonically with increased concentration of tetraethylammoniumtetrafluoroborate in the ternary electrolyte.[16]To quantify the dual-solute effects for the $\mathrm{Fe}(\mathrm{bpy})_{3}\left(\mathrm{BF}_{4}\right)_{2} / \mathrm{Fc} 1 \mathrm{~N} 112-\mathrm{BF}_{4}$ chemistries, a UVVis absorbance studydemonstrates the effect of supporting salt concentration on active material solubilities. This methodology does not map the entire chemical space, but does demonstrate the utility of minimizing supporting salt content to maximize active species solubility. Fc1N112-BF $4 / \mathrm{TBABF}_{4} / \mathrm{MeCN}$ and $\mathrm{Fe}(\mathrm{bpy})_{3}\left(\mathrm{BF}_{4}\right)_{2} / \mathrm{TBABF}_{4} / \mathrm{MeCNare}$ the ternary electrolytes of interest. Table 1 displays the solubilities of $\mathrm{Fe}(\mathrm{bpy})_{3}\left(\mathrm{BF}_{4}\right)_{2}$ and Fc1N112-BF 4 in MeCNwith either $0 \mathrm{M}$ or $\sim 0.5 \mathrm{M}$ supporting salt. The solubilities of both active materials decrease significantly $\left(50 \%\right.$ for $\mathrm{Fe}(\mathrm{bpy})_{3}\left(\mathrm{BF}_{4}\right)_{2}$ and $27 \%$ for $\mathrm{Fc} 1 \mathrm{~N} 112-$ $\mathrm{BF}_{4}$ ) with $\sim 0.5 \mathrm{M} \mathrm{TBABF}_{4}$ in solution.For application in a commercial asymmetric RFB system, identifying the active material solubilities in the quaternary 
$\mathrm{Fe}(\mathrm{bpy})_{3}\left(\mathrm{BF}_{4}\right)_{2} / \mathrm{Fc} 1 \mathrm{~N} 112-\mathrm{BF}_{4} / \mathrm{TBABF}_{4} / \mathrm{MeCN}$ mixed electrolyte system would be crucial to avoid active material precipitation.Nonetheless, this preliminary solubility study demonstrates that by implementing a common ion exchange NAqRFB configuration, the concentration of supporting salt can vary independently from the active material concentration to optimize active material solubility and electrolyte conductivity.

\begin{tabular}{|l|c|c|}
\hline $\begin{array}{l}\text { Active } \\
\text { Material }\end{array}$ & $\begin{array}{c}\text { TBABF }_{4} \\
\text { Concentration (M) }\end{array}$ & $\begin{array}{c}\text { Active Species } \\
\text { Solubility (M) }\end{array}$ \\
\hline $\mathrm{Fe}(\mathrm{bpy})_{3}\left(\mathrm{BF}_{4}\right)_{2}$ & 0 & 0.6 \\
\hline $\mathrm{Fe}(\mathrm{bpy})_{3}\left(\mathrm{BF}_{4}\right)_{2}$ & $\sim 0.5$ & 0.3 \\
\hline $\mathrm{Fc} 1 \mathrm{~N} 112-\mathrm{BF}_{4}$ & 0 & 1.9 \\
\hline $\mathrm{Fc} 1 \mathrm{~N} 112-\mathrm{BF}_{4}$ & $\sim 0.5$ & 1.4 \\
\hline
\end{tabular}

Table 1: Active species solubilities with and without supporting salt in MeCN.

To enable cost-effective NAqRFBs, electrolytes must exhibit sufficiently high energy density to offset additionalsystem costs (e.g. chemicals, balance of plant).Increasing the solubility per accessed electron or cell potential can deliver higher energy densities, and as illustrated in Table 1, common ion cell configurations facilitate the former approach. Darling et al. suggested that for NAqRFBs to achieve a $\$ 150 \mathrm{kWh}^{-1}$ system price, including installation and invertor costs, thesolubility per accessed electron must be 4 $5 \mathrm{M}$. [5] For a $1 \mathrm{e}^{-}$transfer NAqRFB, this requirement implies a minimum solubility of $4-5$ $M$. Since the electrolyte would require an additional $4-5 \mathrm{M}$ supporting salt, the total concentration of active species and supporting salt would be $8-10 \mathrm{M}$. Most nonaqueous solvents (e.g. MeCN, propylene carbonate, dimethoxyethane) cannot achieve such high solute concentrations without significantly increasing temperatureor employing ionic liquid solvents. Ionic liquidswouldafford charge balance, but can cost 520 times more than molecular solvents.[37]A high concentration salt splitting NAqRFB employing molten organic redox active compounds with dissolved salt[38,39]or deep eutectic electroactive melts[40,41] may be possible but, with limited reports, the feasibility of these systems remains relatively unexplored. For near term NAqRFB prototypes, a common ion configuration will enable low cost electrolytes and energy dense batteries.

\subsection{Compatibility and Stability}

\subsubsection{Cyclic Voltammetry}


Cyclic voltammetry (CV) providesan initial assessment ofthe electrochemical compatibility of the various active species and supporting electrolyte on a short time scale. Figure 2 shows CVs of both the individual species and an equi-molar mixture. $\mathrm{Fe}(\mathrm{bpy})_{3}\left(\mathrm{BF}_{4}\right)_{2}$ demonstrates four quasi-reversible redox couples $(-2.08,-1.85,-1.65$, and $0.74 \mathrm{~V}$ vs. $\left.\mathrm{Ag} / \mathrm{Ag}^{+}\right)$with the single positive redox event (V)associated with theFe"/Fe"ltransition and the three negative couples(I, II, III) corresponding to ligand-

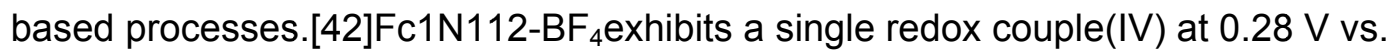
$\mathrm{Ag} / \mathrm{Ag}^{+}$, with no other redox activity within the potential window where $\mathrm{Fe}(\mathrm{bpy})_{3}\left(\mathrm{BF}_{4}\right)_{2}$ is active. The redox potentials of the five electron transfer events agree with previous literature reports.[8,28,31]The CV of the mixture is essentially a combination of those for the individual species, indicating that these materials are chemically and electrochemically compatible, at least for the time scales of thisCV experiment.

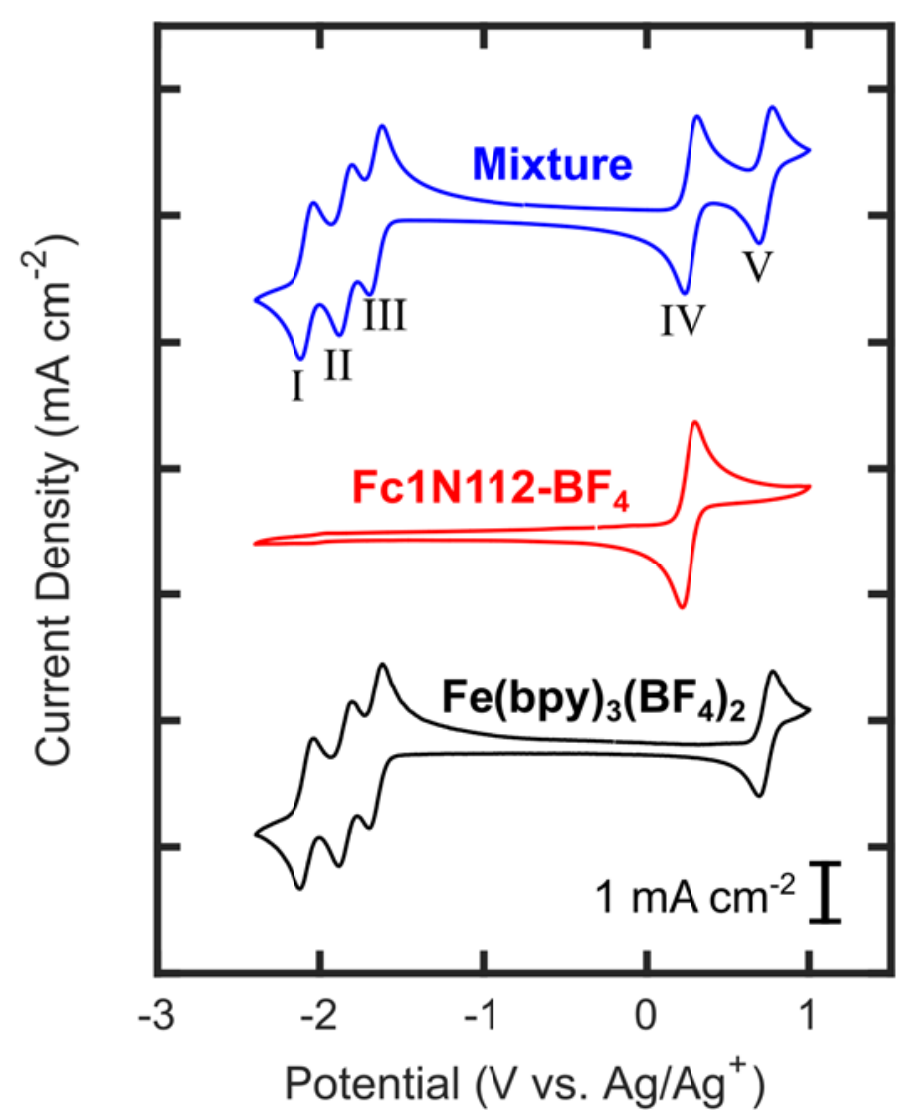

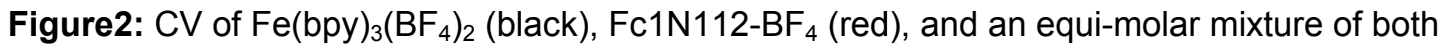
(blue). 
Pairing couple III ofFe(bpy $)_{3}\left(\mathrm{BF}_{4}\right)_{2}$ withFc1N112-BF 4 (IV) produces a $1 \mathrm{e}^{-}, 1.92 \mathrm{~V}$ cell. This cell offers an increased cell potential over several aqueous systems, but NAqRFBs will require even higher voltages $(\geq 3 \mathrm{~V})$ for economic feasibility.[5] One of the most promising strategies to increase the energy density of NAqRFBs is to utilize multiple electron transfers. For this system, pairing two of the negative couples of $\mathrm{Fe}(\mathrm{bpy})_{3}\left(\mathrm{BF}_{4}\right)_{2}$

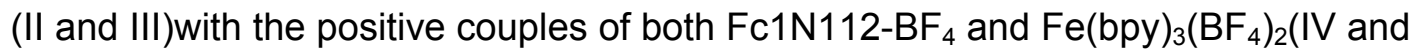
V)results in a $2 e^{-}$transfer cell. The use of $\mathrm{Fc} 1 \mathrm{~N} 112-\mathrm{BF}_{4}$ providesthe additional capacity required on the posolyte side to afford a multi-electron transfer cell. This eliminates the need to double the concentration of the posolyte material, which would be necessary ifemploying only a single positive couple.[26,28]Additionally, the positive redox couples are easily distinguishable, aiding in visualizationof charge/discharge events. The average cell potential for this $2 \mathrm{e}^{-}$system is $2.25 \mathrm{~V}$, which when coupled with theuse of multiple redox events, provides a cell with more than twice thetheoretical energy densityof the analogous single electron system.

\subsubsection{Bulk Electrolysis}

Bulk electrolysis experiments were used to further characterize the electrochemical compatibility of $\mathrm{Fe}(\mathrm{bpy})_{3}\left(\mathrm{BF}_{4}\right)_{2}$ and $\mathrm{Fc} 1 \mathrm{~N} 112-\mathrm{BF}_{4}$, andto assess the feasibility of employing these species in an asymmetric flowcell. Cycling experiments on each individual component first establishthe baseline stability and then cycling a mixture of the two species helps identify any interactions between $\mathrm{Fe}(\mathrm{bpy})_{3}\left(\mathrm{BF}_{4}\right)_{2}$ and $\mathrm{Fc} 1 \mathrm{~N} 112-\mathrm{BF}_{4}$. 

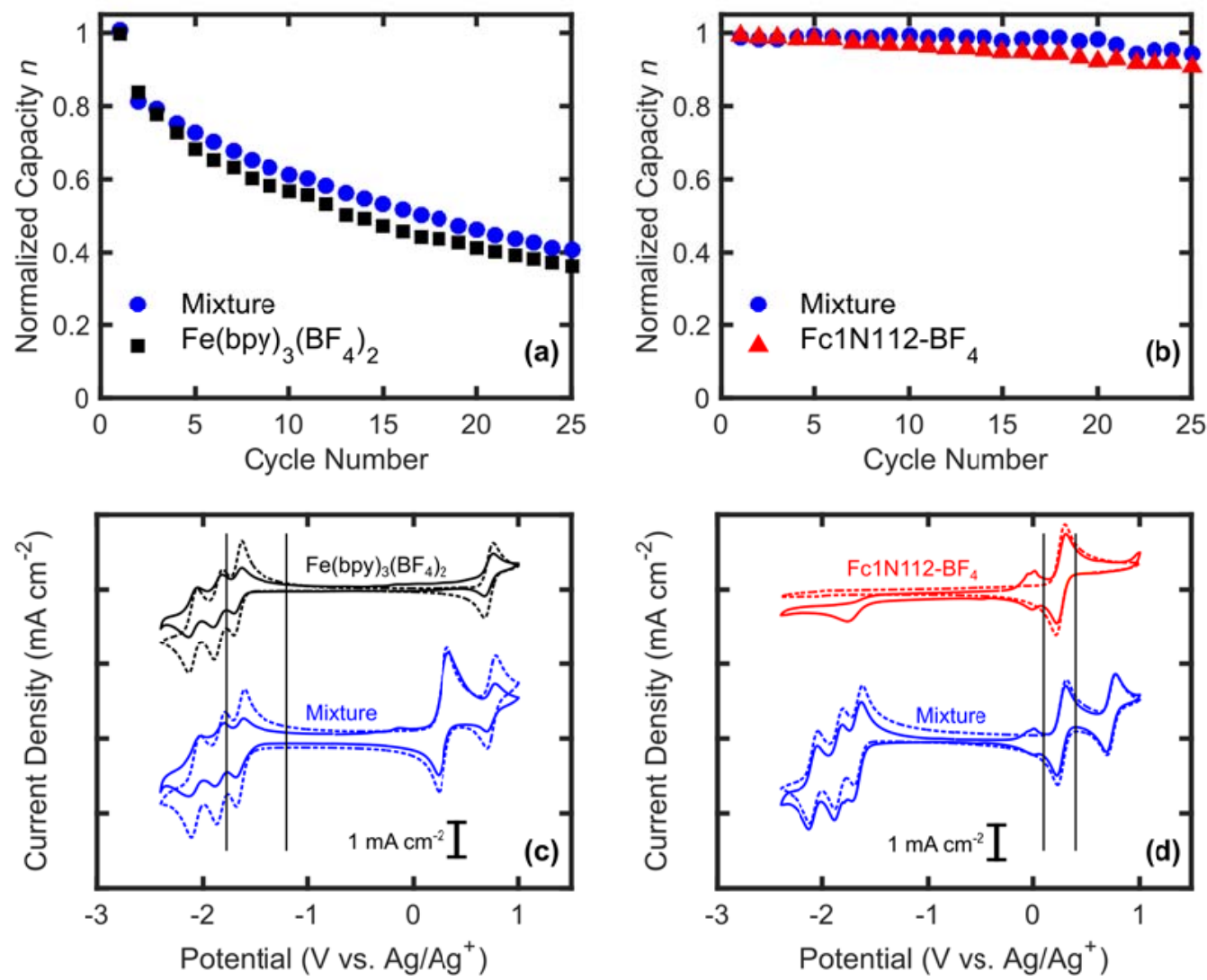

Figure 3: Capacity retention measured by bulk electrolysis for $\mathrm{Fe}(\mathrm{bpy})_{3}\left(\mathrm{BF}_{4}\right)_{2}(\mathrm{black})$, Fc1N112$\mathrm{BF}_{4}$ (red), and an equi-molar mixture of $\mathrm{Fe}(\mathrm{bpy})_{3}\left(\mathrm{BF}_{4}\right)_{2} / \mathrm{Fc} 1 \mathrm{~N} 112-\mathrm{BF}_{4}($ blue $)$ through (a) a single negative $\mathrm{e}^{-}$and (b) a single positive $\mathrm{e}^{-}$. (c, d) CVsbefore (dashed) and after cycling (solid) are shown for each case, with the black vertical lines denoting the potential cutoffs used during cycling.

Figure 3 displays capacity retention plots and CVs for the $1 \mathrm{e}^{-}$system (III and IV). Through a single negative electron transfer (III), $\mathrm{Fe}(\mathrm{bpy})_{3}\left(\mathrm{BF}_{4}\right)_{2}$ shows significant capacity fade (Figure 3a), in agreement with previous reports.[24] Examination of the CV after cycling (Figure 3c) reveals a decrease in peak heights for all couples associated with $\mathrm{Fe}(\mathrm{bpy})_{3}\left(\mathrm{BF}_{4}\right)_{2}$, supporting the observed capacity fade.No new redox processes arise, suggesting that the reaction byproducts are either electrochemically inactive within the potential window of interest or insoluble in the electrolyte solution. A comparison with the mixture, cycled under identical conditions, reveals near identical capacity fade and similar degradation (indicated by CV), suggesting minimal interactions between the active species; the majority of the capacity fade arises from $\mathrm{Fe}(\mathrm{bpy})_{3}\left(\mathrm{BF}_{4}\right)_{2}$ instability. The Fc1N112-BF 4 couple does lose some peak intensity, indicating minor interactions with the $\mathrm{Fe}(\mathrm{bpy})_{3}\left(\mathrm{BF}_{4}\right)_{2}$, however, this couple does not play a role in the negolyte cell chemistry and should have minimal effect on cell performance. Analysis of the single 


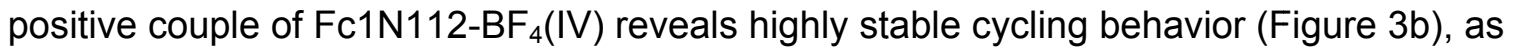
expected based on previous reports.[8] CVs after cycling (Figure 3d)show a minimal decrease in peak height for the Fc1N112-BF 4 , which correlates with the observed capacity fade. For both the single species and the mixture, electrochemically active degradation productsare observed at 0 and $-1.7 \mathrm{~V} v \mathrm{~s}$. $\mathrm{Ag} / \mathrm{Ag}^{+}$. These peaks could be

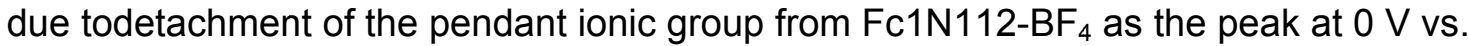
$\mathrm{Ag} / \mathrm{Ag}^{+}$matches the redox potential of ferrocene.[43]Nosubstantial changes are observed forthe peaks associated withFe (bpy $)_{3}\left(\mathrm{BF}_{4}\right)_{2}$.In all cases, the potential curves (Figure S6) match the potentials expected based on the initial CV.Taken as a whole, the near identical capacity fade and degradation products observed after cyclingfor both the single active species and the mixtureestablish that $\mathrm{Fc} 1 \mathrm{~N} 112-\mathrm{BF}_{4}$ and $\mathrm{Fe}(\mathrm{bpy})_{3}\left(\mathrm{BF}_{4}\right)_{2}$ are compatible chemistries for use in a $1 \mathrm{e}^{-}$asymmetric NAqRFB.
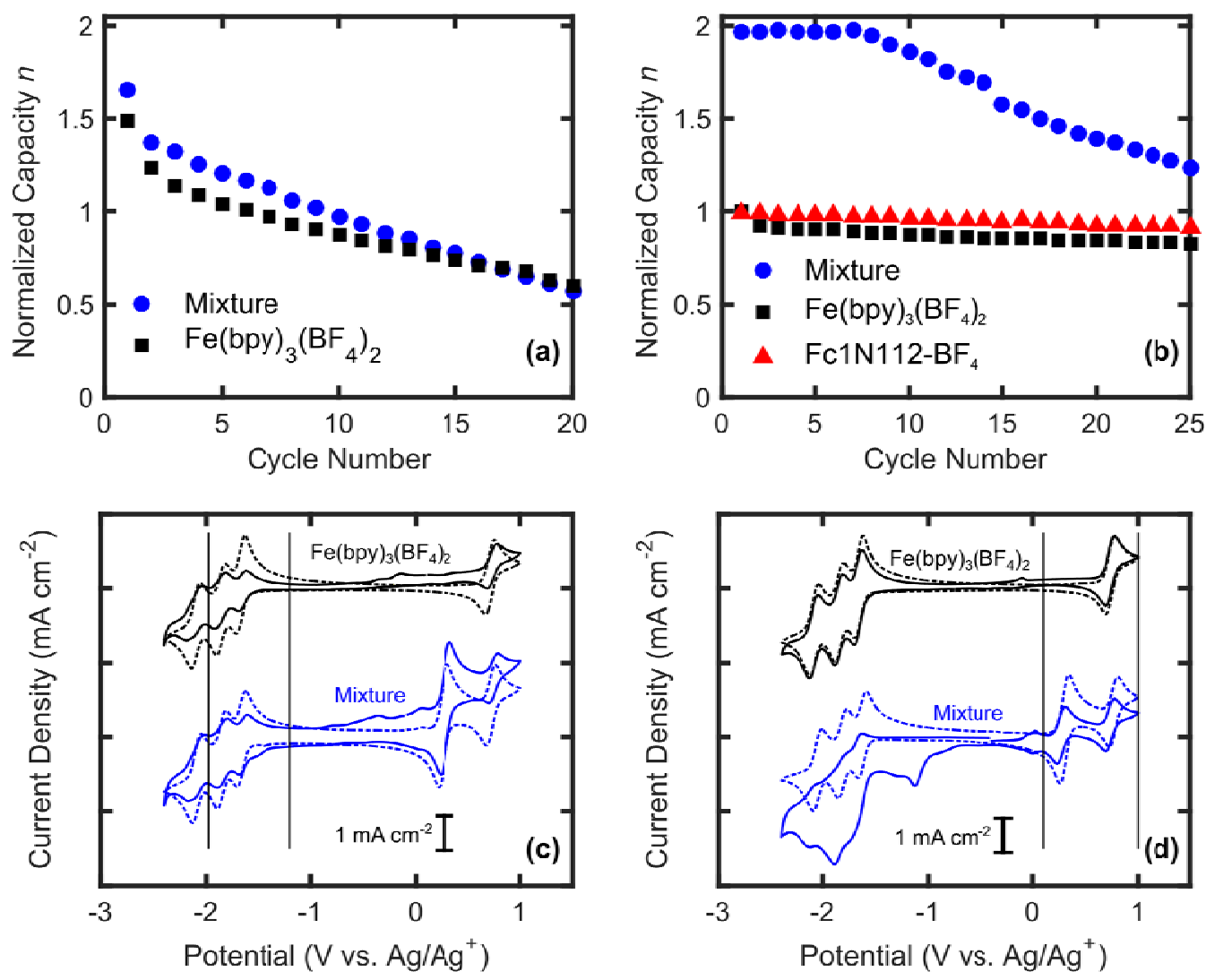

Figure 4: Capacity retention measured by bulk electrolysis for $\mathrm{Fe}(\mathrm{bpy})_{3}\left(\mathrm{BF}_{4}\right)_{2}$ (black), Fc1N112-BF 4 (red) and an equi-molar mixture of $\mathrm{Fe}(\mathrm{bpy})_{3} / \mathrm{Fc} 1 \mathrm{~N} 112-\mathrm{BF}_{4}(\mathrm{blue})$ through (a) two negative $\mathrm{e}^{-}$and (b) both one and two positive $\mathrm{e}^{-}$. (c, d)CVs before (dashed) and after cycling (solid) are shown for each case, with the black vertical lines denoting the potential cutoffs used during cycling. 
The $2 \mathrm{e}^{-}$system utilizes two negative couples (II and III) from $\mathrm{Fe}(\mathrm{bpy})_{3}\left(\mathrm{BF}_{4}\right)_{2}$ and the

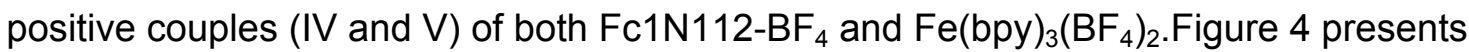
cycling data and $\mathrm{CVs}$ for the $2 \mathrm{e}^{-}$bulk electrolysis experiments.Cycling through the two negative couples (II and III) reveals minimal interactions between the active species (Figure $4 \mathrm{a}$ and $4 \mathrm{c}$ ). For both $\mathrm{Fe}(\mathrm{bpy})_{3}\left(\mathrm{BF}_{4}\right)_{2}$ and a mixture of the two species, the capacity fade profile is very similar (Figure 4a). In both cases, cycling neverreaches the theoretical capacity due to theclose proximity of couple I; a voltage cutoff ensured that the cell cycled only through couples II and III, subsequently limiting charge capacity. Examination of the CV after cycling (Figure 4c) shows a decrease in the peak height of the $\mathrm{Fe}(\mathrm{bpy})_{3}\left(\mathrm{BF}_{4}\right)_{2}$ couples, similar to that observed for the $1 \mathrm{e}^{-}$transfer. In the case of the mixture, evidence of minor degradation products appear in the CV at the same potentials

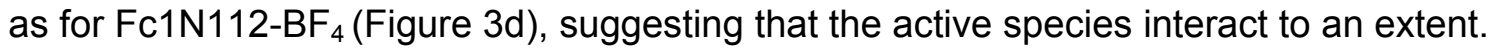
Despite the development of these new irreversible electrochemical processes, the cycling behavior confirms that these two redox couples are compatible for use on the negative side of a multi-electron transfer cell.

Cycling data through the two positive redox couples shows the highest degree of interactions observed for these two chemistries. Bulk electrolysis through the single positive couple of each individual species reveals stable cycling behavior (Figure 4b), and CVs after cycling show minimal degradation for both $\mathrm{Fc}^{\mathrm{N} 112-\mathrm{BF}_{4}}$ (Figure 3d) and $\mathrm{Fe}(\mathrm{bpy})_{3}\left(\mathrm{BF}_{4}\right)_{2}$ (Figure $\left.4 \mathrm{~d}\right)$. The mixed positive couples, however, exhibit significant capacity fade after the first 8 cycles (Figure $4 b$ ). Analysis of the CV after cycling shows clear evidence of degradation (Figure 4d). Peak heights for both positive couples decrease while those for the negative couples of $\mathrm{Fe}(\mathrm{bpy})_{3}\left(\mathrm{BF}_{4}\right)_{2}$ degrade completely. Despite the significant capacity fade and interactions observed over time for the mixture at positive potentials, the cell maintainsa constant capacity for at least the first 8 cycles, and therefore, affords a cell to demonstrate a multi-electron system.

\subsection{Cell Performance}

\subsubsection{H-Cell Cycling}

$\mathrm{H}$-type cell experiments demonstrate cycling of the $1 \mathrm{e}^{-}$and $2 \mathrm{e}^{-}$ $\mathrm{Fe}(\mathrm{bpy})_{3}\left(\mathrm{BF}_{4}\right)_{2} / \mathrm{Fc} 1 \mathrm{~N} 112-\mathrm{BF}_{4}$ systems at non-dilute concentrations in the absence of 
flow. These H-cell experiments utilizequasi-reference electrodes in each chamber to monitor electrode potentials and confirm the accessed redox couples during cycling. Both sides of the cell contained an identical mixture of $\mathrm{Fe}(\mathrm{bpy})_{3}\left(\mathrm{BF}_{4}\right)_{2} / \mathrm{Fc} 1 \mathrm{~N} 112-\mathrm{BF}_{4}$ to ensure any capacity fade is due primarily to degradation of the active species, not irreversible crossover. Crossover will occur due to the formation of concentration gradients during cycling, but should only lead to decreased coulombic efficiency, not capacity fade. Figures $5 \mathrm{a}$ and $5 \mathrm{~b}$ show potential curves for the $1 \mathrm{e}^{-}$and $2 \mathrm{e}^{-} \mathrm{H}$-cell cycling experiments, respectively. Figures $5 c$ and $5 d$ display electrode potentials for the $1 e^{-}$and $2 \mathrm{e}^{-}$cells, respectively.

For the $1 \mathrm{e}^{-}$system, the negative electrode potential matchesthe potential of couple III, while the positive electrode potential matches that for couple IV. These results confirm that the $\mathrm{Fe}(\mathrm{bpy})_{3}\left(\mathrm{BF}_{4}\right)_{2} / \mathrm{Fc} 1 \mathrm{~N} 112-\mathrm{BF}_{4}$ cell accesses only the desired couples, while reaching $100 \%$ of the theoretical capacity $\left(1.34 \mathrm{AhL}^{-1}\right)$ on the first cycle, further establishing the compatibility of the selected active species.Figure $5 a$ does reveala large cell overpotential $(\sim 0.45 \mathrm{~V})$ during cycling, comparable to other $\mathrm{H}$-cell cycling reports.[25]Ohmic losses constitute a majority ( $\sim .4 \mathrm{~V})$ of the observed overpotential, due to the wide inter-electrode separation, andthe remaining overpotential isdue to activation and concentration polarization losses. Because of these significant overpotentials, the average voltaic efficiency is only $60 \%$. The coulombic efficiency is also relatively low $(73 \%)$ due to the high permeability of the Daramic separator. 

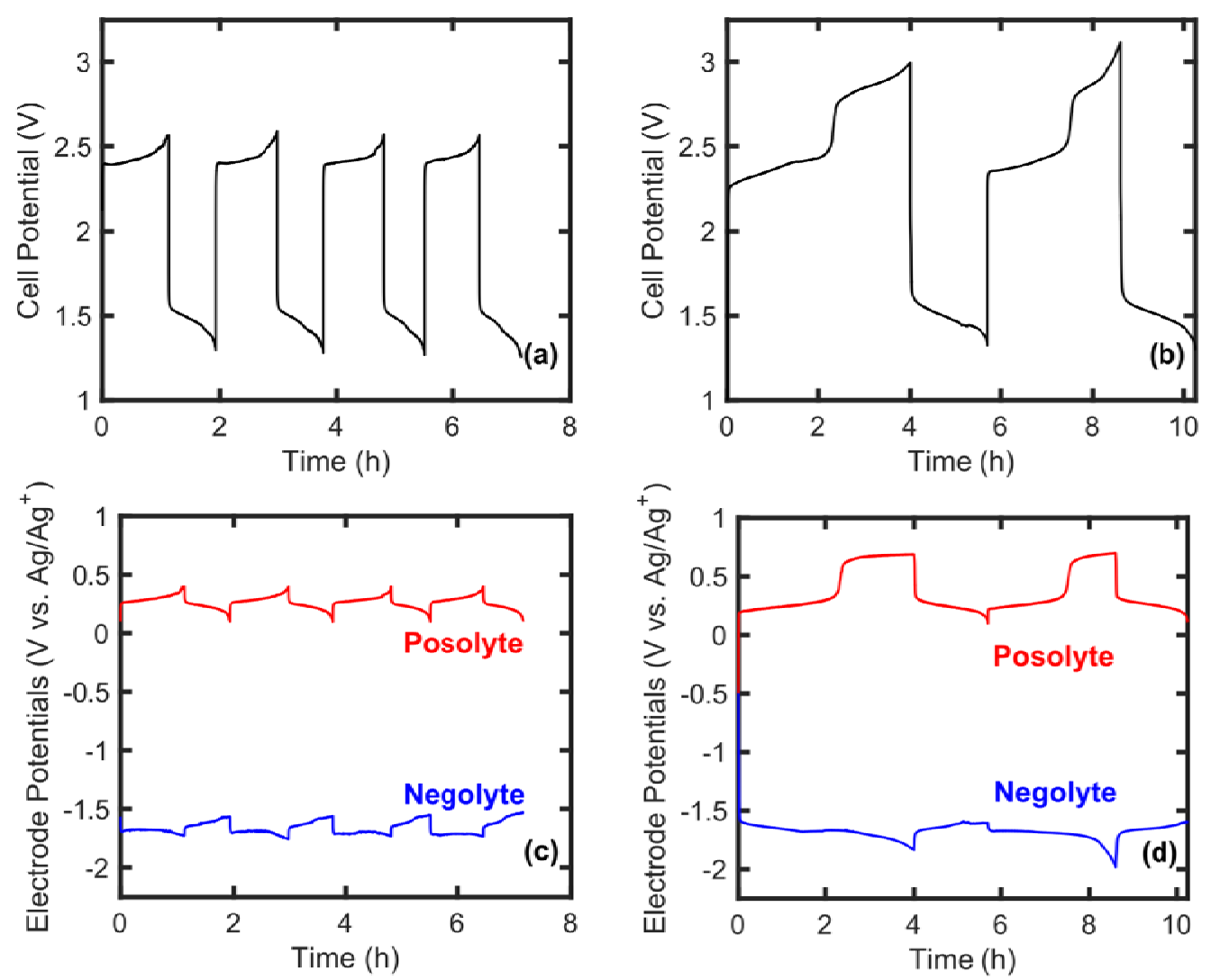

Figure 5: H-cell cycling data for the $\mathrm{Fe}(\mathrm{bpy})_{3}(\mathrm{BF})_{4} / \mathrm{Fc} 1 \mathrm{~N} 112-\mathrm{BF}_{4}$ systemshowing the total cell potential for the (a) $1 \mathrm{e}^{-}$and (b) $2 \mathrm{e}^{-}$experiments, and theposolyte (red) and negolyte (blue) potentials for the (c) $1 \mathrm{e}^{-}$and (d) $2 \mathrm{e}^{-} \mathrm{H}$-cells, measured using $\mathrm{Ag} / \mathrm{Ag}^{+}$quasi-reference electrodes in each chamber. The theoretical cell capacities are $1.34 \mathrm{AhL}^{-1}$ and $2.68 \mathrm{AhL}^{-1}$ for the $1 \mathrm{e}^{-}$and $2 \mathrm{e}^{-}$ cells, respectively.

Quasi-reference electrodes in the $2 \mathrm{e}^{-} \mathrm{H}$-cell experiment confirm that the cell accesses allof the desired couples (II, III, IV, and V)upon charging. Considering Figure $5 \mathrm{~d}$, the posolyte first charges through the positive couple IV of Fc1N112-BF 4 at $0.28 \mathrm{~V}$ vs. $\mathrm{Ag} / \mathrm{Ag}^{+}$, and once couple IV is exhausted, the cell activates couple $\mathrm{V}$ of $\mathrm{Fe}(\mathrm{bpy})_{3}\left(\mathrm{BF}_{4}\right)_{2}$ at $0.75 \mathrm{~V}$ vs. $\mathrm{Ag} / \mathrm{Ag}^{+}$. Both plateaus are visible in the charging profile and match the potentials expected based on $\mathrm{CV}$. For the negative side, the switch from couples III to II of $\mathrm{Fe}(\mathrm{bpy})_{3}\left(\mathrm{BF}_{4}\right)_{2}$ is less pronounced due to the close proximity of these couples, but a change in the slope of the charging curve after $\sim 2 \mathrm{~h}$ indicates that the cell accessesboth of these redox couples. On the first charge, the cell reaches $100 \%$ of the theoretical capacity $\left(2.68 \mathrm{AhL}^{-1}\right)$, however, on discharge the cell only accesses the positive couple IV of Fc1N112-BF . The separator allows significantself-discharge, and a high rate of crossover causedthe charged $\mathrm{Fe}(\mathrm{bpy})_{3}\left(\mathrm{BF}_{4}\right)_{3}$ to fully self-discharge before partaking in an electrode reaction. The average coulombic efficiency for the $2 \mathrm{e}^{-}$cell is 
$50 \%$, due to the high rate of crossover, and the voltaic efficiency is $58 \%$. Similar to the $1 \mathrm{e}^{-}$cell, this is primarily due to a large cell overpotential. For the $2 \mathrm{e}^{-}$cell, however,the inability to discharge through both couples results in an even lower voltaic efficiency. In this case, the voltaic efficiency is higher than the coulombic efficiency due to the significant contribution of active species degradation.Despite the inability of this cell to fully discharge, these results demonstrate that the system can access the desired electrons from each of the active species.

\subsubsection{Flow Cell Studies}

Our electrochemical studies culminate in flow cell cycling experiments, transitioning the vetted active materials to a laboratory prototype. Flow cells achieve higher current densities than $\mathrm{H}$-cells, due to a significantly lower ASR, overcoming crossover limitations and offering higher voltaic efficiencies. The ASR of theflow cell is $\sim 36 \Omega \mathrm{cm}^{2}$, measured via electrochemical impedance spectroscopy (Figure S8) prior to beginning cycling experiments. From the measured solubilities (Table 1), in the presence of salt, the solubility of $\mathrm{Fe}(\mathrm{bpy})_{3}\left(\mathrm{BF}_{4}\right)$ limits the maximum theoretical energy density of the electrolyte to $15.3 \mathrm{WhL}^{-1}$ for the $1 \mathrm{e}^{-}$transfer system and $36.2 \mathrm{Wh} \mathrm{L}^{-1}$ for the $2 \mathrm{e}^{-}$system. Since flow cell experiments in this study employ only $0.1 \mathrm{M}$ active material, the achievable energy densitiesin this experimental work are5.1 $\mathrm{Wh} \mathrm{L}^{-1}$ and $12.1 \mathrm{Wh} \mathrm{L}^{-1}$ for the $1 \mathrm{e}^{-}$and $2 \mathrm{e}^{-}$transfer systems, respectively.

A small-scale flow cell demonstrates $1 \mathrm{e}^{-}$cycling for a battery employing redox couples III and IV.Charge/discharge profiles in Figure 6aexhibit a single potential plateau that corresponds to the expected $1 \mathrm{e}^{-}$process. The theoretical capacity of the $1 \mathrm{e}^{-}$transfer cell was $2.68 \mathrm{Ah} \mathrm{L}^{-1}$, and the flow cell accesses $66 \%$ of this capacity during the first cycle. This relatively low depth-of-charge isa result of the upper cell potential cutoff of $2.01 \mathrm{~V}$, selected to avoid accessing additional redox couples (II or V).Figure 6billustrates the charge and discharge capacities as a function of cycle number. Over the first 5 cycles, the charge capacity is significantly greater than the discharge capacity, resulting in coulombic efficiencies $<80 \%$, as depicted in Figure 7c. Active species crossover and subsequent self-discharge through the Daramic separator, combined with active species degradation, led to the low coulombic efficiencies. The coulombic efficiency improves from $70 \%$ to $90 \%$ over 20 cycles, with a mean value of $81 \%$,due to decreasing depthsof-charge as the experiment progresses. A prior NAqRFB study employing a Daramic 
separator with similar active species concentrations and current densities reported comparable coulombic efficiencies. [20] The voltaic efficiency is nearly constant as a function of cycle number, with a mean value of $91 \pm 0.2 \%$. The voltaic efficiency is relatively high due to two factors. First, the Daramic separator exhibits a lower ASR compared to other NAqRFB separators[8,19,21,27,33,44] as a result of its high porosity and the high conductivity of the electrolyte phase. Second, the voltaic efficiency is high in comparison to many AqRFBs due to lower current densities and a higher cell voltage; overpotential losses constitute a smaller fraction of the total cell potential. As with the $2 \mathrm{e}^{-}$ $\mathrm{H}$-cell experiment, the voltaic efficiency is higher than the coulombic efficiency due to the significant contribution of active species degradation to the low coulombic efficiency. The range of coulombic efficiencies observed during cycling further supports this result. As the cell capacity stabilizes, indicating that active species degradation has slowed, the coulombic efficiency approaches the voltaic efficiency, as would be expected for a stable system.

Capacity fadefor the flow cell experiment is in agreement with the limited stability ofFe $(\mathrm{bpy})_{3}\left(\mathrm{BF}_{4}\right)_{2}$ observed during bulk electrolysis experiments. For couple III of $\mathrm{Fe}(\mathrm{bpy})_{3}\left(\mathrm{BF}_{4}\right)_{2}$, the capacityfades to $47 \%$ of its initial charge capacity after 20 bulk electrolysis cycles.Since the flow cell never reaches the theoretical capacity, flow cell cycling demonstrates slightly slower fade to only $62 \%$ of its initial charge capacity over 20 cycles. 

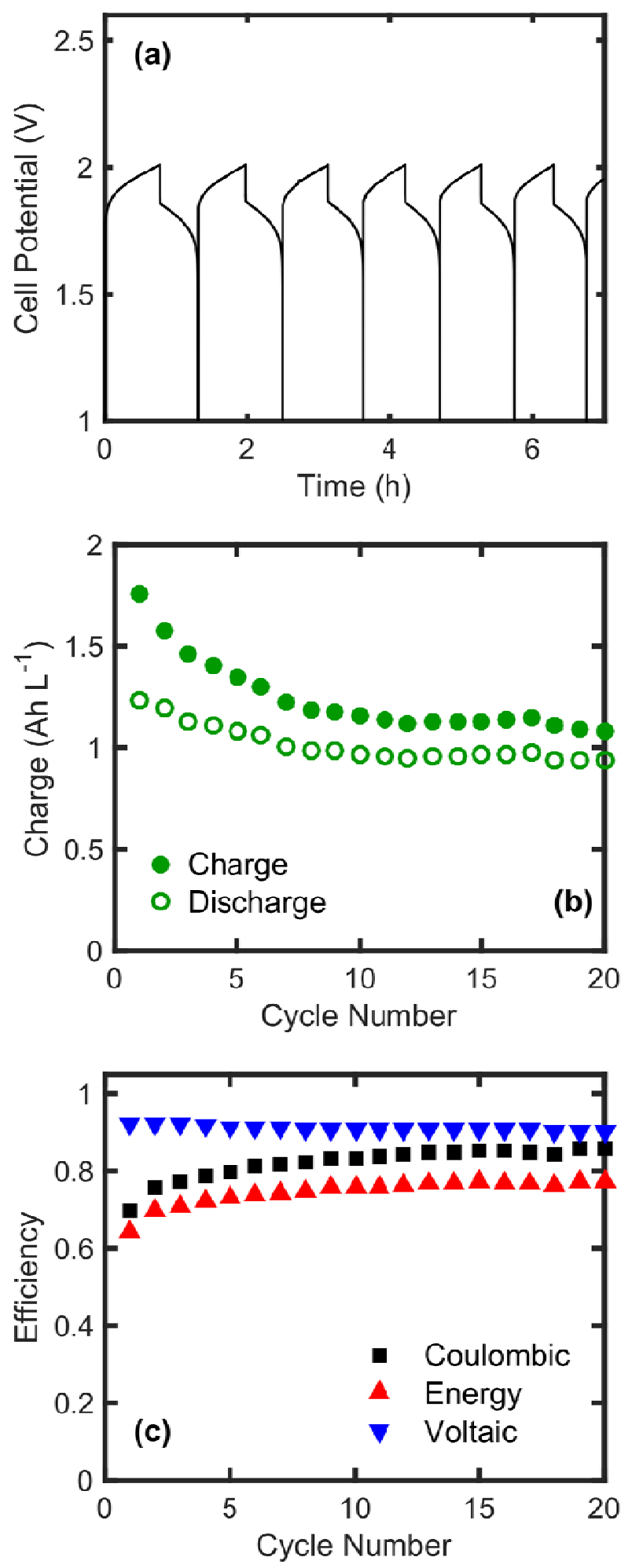

Figure 6: $\mathrm{Fe}(\mathrm{bpy})_{3}(\mathrm{BF})_{4} / \mathrm{Fc} 1 \mathrm{~N} 112-\mathrm{BF}_{4}$ 1e- transfer flow cell cycling performance: (a)charge and discharge potential curves as a function of time, $(\mathbf{b})$ charge $(\mathbf{O})$ and discharge $(\mathrm{O})$ capacities as a function of cycle number, and (c)coulombic $(\boldsymbol{\nabla})$, energy $(\boldsymbol{\Delta})$, and voltaic $(\boldsymbol{\nabla})$ efficiencies as a function of cycle number. The theoretical cell capacity is $2.68 \mathrm{Ah} \mathrm{L}^{-1}$. 
A $2 \mathrm{e}^{-}$flow cell study completes the electrochemical analysis of the $\mathrm{Fe}(\mathrm{bpy})_{3}\left(\mathrm{BF}_{4}\right)_{2} / \mathrm{Fc} 1 \mathrm{~N} 112-\mathrm{BF}_{4}$ system. As shown in Figure $7 \mathrm{a}$, the2e- flow cellaccesses all available redox processes during both charge and discharge, and cycle 1 displays a unique charging profile due to the 4 accessible redox couples in the $\mathrm{Fe}(\mathrm{bpy})_{3}\left(\mathrm{BF}_{4}\right)_{2} / \mathrm{Fc} 1 \mathrm{~N} 112-\mathrm{BF}_{4} 2 \mathrm{e}^{-}$system. Consider Figure $7 \mathrm{~b}$, which plots cell potential as a function of capacity for only the first charging process. The initial charging plateau accesses redox couples III and IV. This behavior is consistent with observations during charging of the $1 \mathrm{e}^{-}$transfer flow cell. As the cell continues to charge, however, a second plateau appears; a non-differentiable decrease in cell potential characterizes the start of the second plateau. As the electrodes continue to polarize, redox couplesII, III, and IV become thermodynamically accessible, but not couple $\mathrm{V}$. Eventually, couple IV is exhausted, and a sharp increase in cell potential marks the start of a third plateau.The third plateau thenaccesses couples II, III, and V.Finally,for a fourth plateau,only couples II and IVparticipate in charge transfer reactions because all other couples have been completely exhausted. Upon cell discharge, two major plateaus appear (Figure 7a), corresponding to the reduction of couple $\mathrm{V}$, followed by the reduction of couple IV, but detailed processes are indistinguishable. 

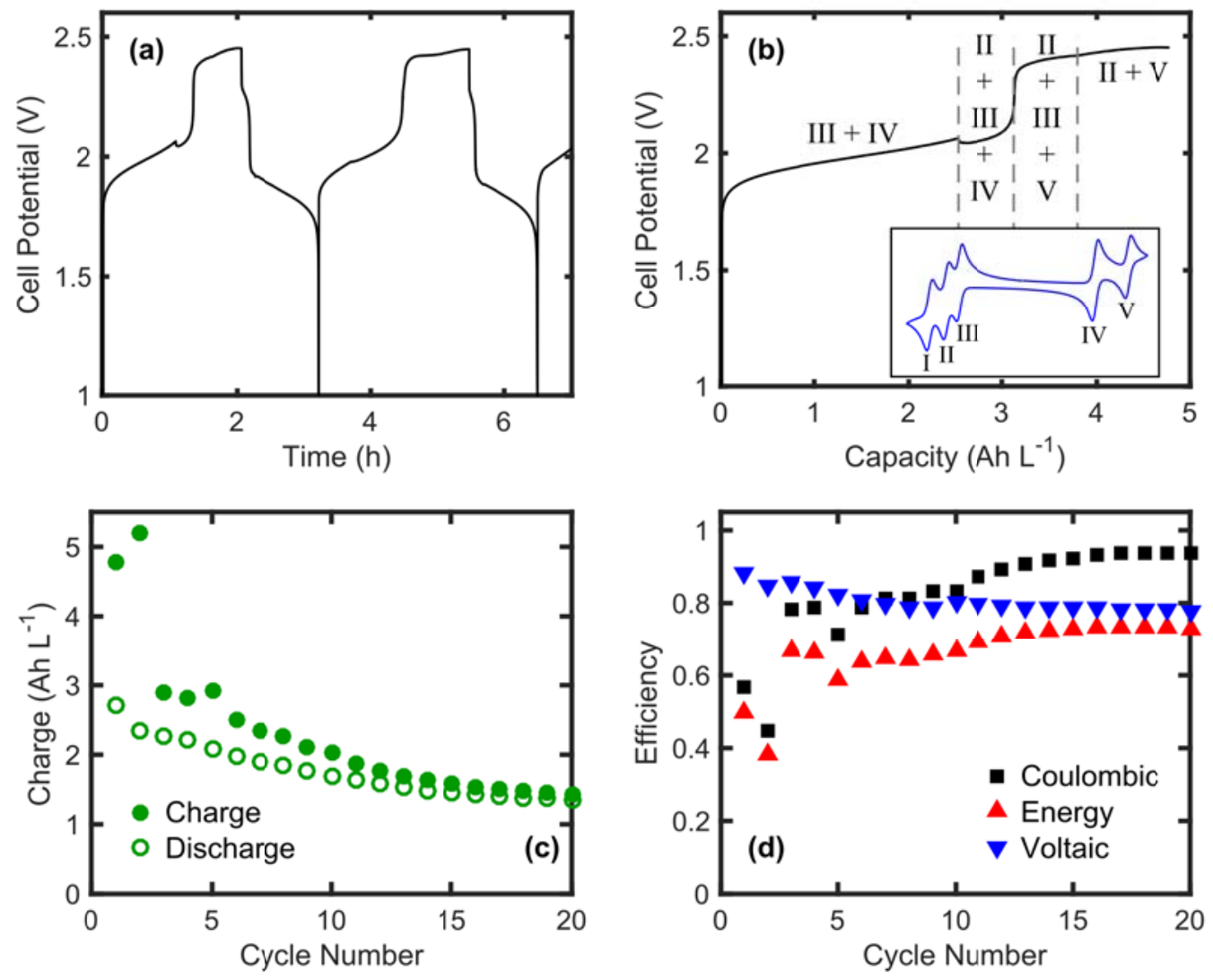

Figure 7: $\mathrm{Fe}(\mathrm{bpy})_{3}\left(\mathrm{BF}_{4}\right)_{2} / \mathrm{Fc} 1 \mathrm{~N} 112-\mathrm{BF}_{4} 2 \mathrm{e}^{-}$transfer flow cell cycling performance: (a) Charge and discharge curves as a function of time, (b)Charging voltage profile as a function of capacity for the $1^{\text {st }}$ cycle, (c)Charge $(0)$ and discharge $(O)$ capacities as a function of cycle number, and (d) Coulombic $(\mathbf{\square})$, energy $(\boldsymbol{\Delta})$, and voltaic $(\boldsymbol{\nabla})$ efficiencies as a function of cycle number. The theoretical cell capacity is $5.36 \mathrm{Ah} \mathrm{L}^{-1}$.

The unconventional $2 \mathrm{e}^{-}$charge behavior results from the presence of two pairs of unequally separated redox couples. The decrease in cell potential at $\sim 2.5 \mathrm{Ah} \mathrm{L}^{-1}$ during cycle 1charging(see Figure $7 \mathrm{~b}$ )is unusual, but an associated decrease in concentration overpotential reconciles the behavior. During the first charge plateau, the negative electrode continuously consumesreactant for couple III, and the negative electrode overpotentialincreases to maintain constant current, subsequently increasing the total cell potential. Unique to this multi-electron transfer system, at a significantly large overpotential on the negative electrode, couple II becomes nearly instantaneously accessible. During the second plateau, the negative electrodecould reduce either couple II or III, increasing reactant concentration as compared to the end of the first plateau. With an increase in available reactant, the negative electrode concentration overpotential decreases, subsequently decreasing the overall cell potential instantaneously at $\sim 2.5 \mathrm{Ah} \mathrm{L}^{-1}$. Bulk electrolysis (Figure S7) and H-cell (Figure 4, 
negolyte) cycling curves confirm this behavior. Additionally, replicate flow cell experiments displayed the same potential dip phenomena during charging.

The theoretical capacity of the $2 \mathrm{e}^{-}$flow cell is $5.36 \mathrm{Ah} \mathrm{L}^{-1}$. The upper cell potential cutoff of $2.45 \mathrm{~V}$ prohibits accessing the unstable couple I, but also prohibits the cell from accessing $100 \%$ of its theoretical capacity. Figure $7 \mathrm{~b}$ indicates that the first two charge cycles accessed $89 \%$ and $97 \%$ of the theoretical cell capacity, respectively. Despite the high depth-of-charge during the first two cycles, the coulombic efficiencies for these cycles are $57 \%$ and $45 \%$ (Figure $7 \mathrm{c}$ ). The low coulombic efficiencies are a result of crossover through the Daramic separator and rapid active species degradation. The short discharge plateau for cycle 1 (Figure 7a), demonstrates that discharge processes incorporating redox couple $V$ are short-lived. During cycling, a large volume ( 2 $\mathrm{mL})$ of electrolyte migrates from the posolyte to the negolyte, suggesting that active material migration plays a significant role in crossover. The higher cell potential of the $2 \mathrm{e}^{-}$system, relative to the $1 \mathrm{e}^{-}$system, provides a large driving force for active species migration during cycling. Mitigating migration of like-charged active species is a challenge to overcome for common ion exchange NAqRFBs. Diffusive crossover of active material also likely plays a significant role in the low coulombic efficiency during cycles 1 and 2 .

Beyond cycle 2, charge capacities decrease significantly, likely caused by active material degradation and low depths-of-charge. Bulk electrolysis experiments over 20 cycles exhibit rapid capacity degradation down to $71 \%$ and $36 \%$ for the 2 eposolyte and negolyte redox couples, respectively. Further, the distinct charge plateaus identified in cycle 1 mergein subsequent cycles, convoluting specific redox processes in late cycle charge plateaus. This $2 e^{-}$transfer system suffers from poor active material stability and high crossover rates, but, nonetheless, demonstrates for the first time the unique charging characteristics associated with multi-electron RFBs.

\subsection{Chemical Cost $\left(\$ \mathrm{kWh}^{-1}\right)$ Benefit of Common Ion Exchange NAqRFBs}

The techno-economic model defined in Equation 3 comparesthe cost for a common ion configurationto that of a salt splitting cell. Equation 3 defines the chemical cost per total energy stored $(\mathrm{C} / \mathrm{E})$ in $\$ \mathrm{kWh}^{-1}$ based on contributions from the active species, solvent, and salt. Table 2 details all variable definitions.Due to uncertainties in active material cost $\left(c_{m}^{\$}\right)$, calculations considered a low $\left(\$ 5 \mathrm{~kg}^{-1}\right)$ and high $\left(\$ 20 \mathrm{~kg}^{-1}\right)$ value to 
illustrate changes in the model as a function of active material cost.A prior study suggested that tailored molecules could achieve an optimistic cost of $\$ 5 \mathrm{~kg}^{-1}$, [5] defining the lower bound for this analysis. In the particular case of the $\mathrm{Fe}(\mathrm{bpy})_{3}\left(\mathrm{BF}_{4}\right)_{2} / \mathrm{Fc} 1 \mathrm{~N} 112-$ $\mathrm{BF}_{4}$ chemistry, the active species resemble other tetrafluoroborate salts employed in lithium-ion batteries, so the upper bound active material cost for this analysis is $\$ 20 \mathrm{~kg}^{-1}$, a projected future state price of salts for lithium-ion batteries. [5]Our description varies from a previous modelby Darling et al. [5] in that the electrolyte cost is divided into its constituent salt and solvent costs. For simplicity, efficiencies, depth-of-discharge, and reaction stoichiometry equalunity.

$$
\frac{C}{E}=\frac{1}{n F U}\left[M_{m} c_{m}^{\S}+r_{\text {sol }} M_{\text {sol }} c_{\text {sol }}^{\S}+r_{\text {salt }} M_{\text {salt }} c_{\text {salt }}^{\text {s }}\right]
$$

\begin{tabular}{|l|l|l|c|c|}
\hline Variable & Description & Unit & $\begin{array}{l}\text { Common } \\
\text { lon }\end{array}$ & $\begin{array}{l}\text { Salt } \\
\text { Splitting }\end{array}$ \\
\hline$n$ & Number of Electrons & - & 1 \\
\hline$F$ & Faraday Constant & $\mathrm{kA}^{\prime} \mathrm{h} \mathrm{mol}^{-1}$ & 0.026801 \\
\hline$U$ & Cell Potential & $\mathrm{V}$ & 1.9 \\
\hline$M_{m}$ & Active Material Molecular Weight & $\mathrm{kg} \mathrm{mol}^{-1}$ & \multicolumn{2}{|c|}{0.359} \\
\hline$M_{\text {sol }}$ & Solvent Molecular Weight & $\mathrm{kg} \mathrm{mol}^{-1}$ & \multicolumn{2}{|c|}{0.041} \\
\hline$M_{\text {salt }}$ & Salt Molecular Weight & $\mathrm{kg} \mathrm{mol}^{-1}$ & \multicolumn{2}{|c|}{0.329} \\
\hline$r_{\text {sol }}$ & Solvent-to-Actives Molar Ratio & - & \multicolumn{2}{|c|}{-} \\
\hline$r_{\text {salt }}$ & Salt-to-Actives Molar Ratio & - & 0.5 & 1.5 \\
\hline$c_{m}^{\$}$ & Active Material Cost & $\$ \mathrm{~kg}^{-1}$ & \multicolumn{2}{|c|}{$5[5] \mathrm{lor} 20$} \\
\hline$c_{\text {sol }}^{\text {s }}$ & Solvent Cost & $\$ \mathrm{~kg}^{-1}$ & \multicolumn{2}{|c|}{$2[5]$} \\
\hline$c_{\text {salt }}^{\text {s }}$ & Salt Cost & $\$ \mathrm{~kg}^{-1}$ & \multicolumn{2}{|c|}{$20[5]$} \\
\hline
\end{tabular}

Table 2: Equation 3 variable definitions and units. Values of each variable used in the common ion versus salt splitting cost analysis are also provided.
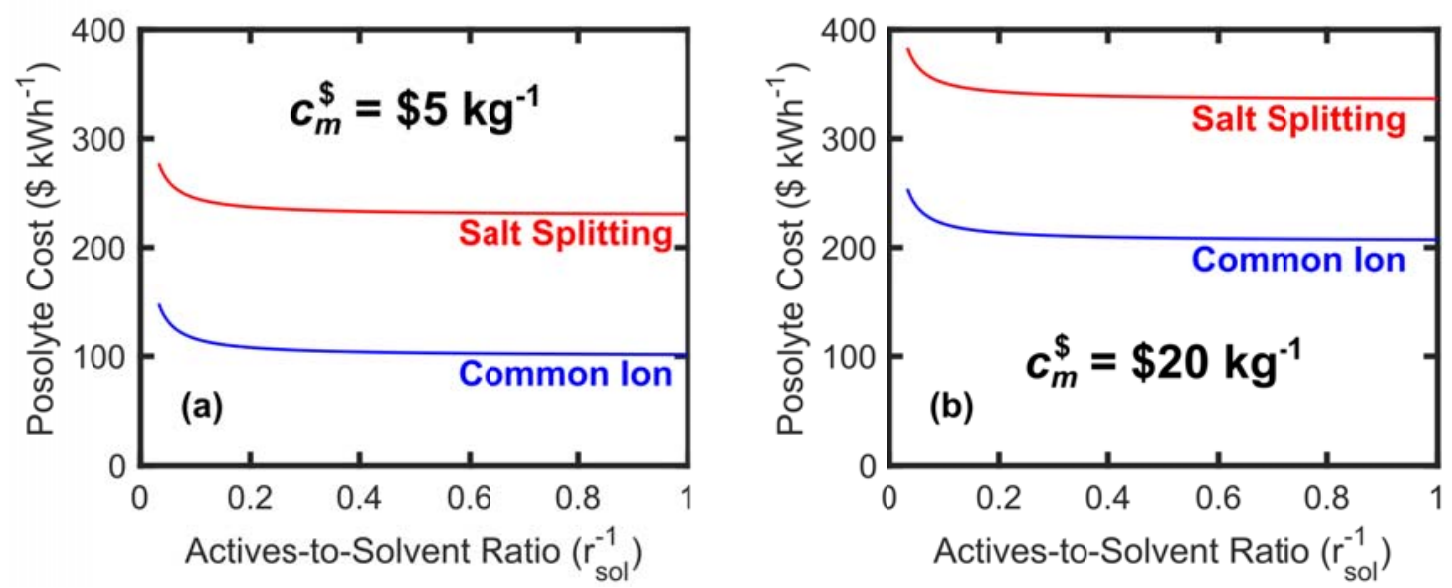
Figure8: Posolyte costs for salt splitting and common ion exchange asymmetric NAqRFBs as a function of molar actives-to-solvent ratio $\left(r_{\text {sol }}^{-1}\right)$, where the active material cost $\left(c_{m}^{\$}\right)$ is (a) $\$ 5 \mathrm{~kg}^{-1}$ or (b) $\$ 20 \mathrm{~kg}^{-1}$. Fc1N112-BF 4 is the sole active material in an unmixed posolyte, and the negolyte active material has a redox potential of $-1.65 \mathrm{~V}$ vs $\mathrm{Ag} / \mathrm{Ag}^{+}$with $1 \mathrm{e}^{-}$transfer. The common ion configuration is cheaper across all values of $r_{\text {sol }}^{-1}$ due to the decreased salt cost.

Figure 8 plots the costs of posolytes in salt splitting and common ion configurations as a function of molar actives-to-solvent ratio $\left(r_{\text {sol }}^{-1}\right)$, clearly demonstrating the economic advantage of common ion exchange. Table 2 lists quantitative details for each variable in the cost analysis, where $\mathrm{Fc} 1 \mathrm{~N} 112-\mathrm{BF}_{4}\left(M_{m}=0.359 \mathrm{~kg} \mathrm{~mol}^{-1}\right)$ is the soleposolyte redox active material (unmixed, asymmetric configuration), $\mathrm{MeCN}$ is the solvent $\left(M_{\text {sol }}=0.041\right.$ $\left.\mathrm{kg} \mathrm{mol}^{-1}\right)$, and $\mathrm{TBABF}_{4}$ is the supporting salt $\left(M_{\text {salt }}=0.329 \mathrm{~kg} \mathrm{~mol}^{-1}\right)$. The negolyteactive material has a redox potential of $-1.65 \mathrm{~V}$ vs $\mathrm{Ag} / \mathrm{Ag}^{+}$, defining the cell potential, but the asymmetric posolyte cost does not account for the cost of the negolyte active material.As illustrated by Figure 8,the cost of both cell configurations decreases as a function of active species concentration, but the common ion cell is less expensive across all concentrations. These chemical cost savings are a result of the decreased salt requirement for common ion exchange NAqRFBs. While varying the active material cost linearly shifts the cost curves to higher and lower values, the cost difference in moving from a salt splitting to common ion configuration remains the same due to an identical savings ( $\$ 129 \mathrm{kWh}^{-1}$ for this particular example) in total salt cost. As previously described, salt-splitting RFBs require a minimum $n: 1$ molar ratio of salt-to-actives $\left(r_{\text {salt }} \geq\right.$ $n$ ) to maintain charge neutrality, while common ion exchange cells can charge balance at any supporting salt concentration $\left(r_{\text {sall }} \geq 0\right)$. The techno-economic analysis uses $r_{\text {salt }}$ values of 0.5 and 1.5 for the salt splitting and common ion NAqRFBs, respectively, representing a salt concentration $0.5 \mathrm{M}$ above the minimum charge balancing salt requirement for each type of cell. In addition to increasing costs, experimental results in Section 3.2show that increasing salt concentration in the electrolyte suppresses active species solubility. Active species with lower solubilities require a higher molar ratio of solvent-to-actives $\left(r_{\text {sol }}\right)$ to dissolve completely all active species and salt in the electrolyte. Since NAqRFBscan have solvent costs $\left(c_{\text {sol }}^{\S}\right)$ on the same order of magnitude as the active species $\left(c_{m}^{\$}\right)$ costs, minimizing $r_{\text {sol }}$ can significantly decrease chemical costs. The posolyte cost as a function of $r_{\text {solasymptotically }}$ approaches a value where the solvent cost contribution is zero $\left(r_{\text {sol }}=0\right)$. Ultimately, common ion exchange cells decrease chemical costs by minimizing both $r_{\text {salt }}$ and $r_{\text {sol. }}$. 
Note, however, that selecting a common ion exchange chemistry often requires active species with high(er) molecular weights. Common ion exchange RFBs must contain ionic active species at $0 \%$ SOC. Functionalization of neutral redox active species can produce redox active ions [8,31], which necessarily will increase the molecular weight of the active species and could also increase active material cost (higher $c_{m}^{\$}$ ) due to additional synthesis steps. Equation 4 defines a dimensionless cost ratio, $\gamma$, to determine whether to employ heavier, ionic active materialsconsidering only the chemical cost. In Equation 4, the subscript $\mathrm{Cl}$ denotes the heavier, common ion compatible active material and the subscriptSS denotes the lighter, salt splitting active material. The cost ratio $y$ compares the cost increase (numerator) of employing a heavier active materialto the cost savings (denominator)associated with the low salt concentration requirement and higher solubility of the common ion compatible active material. If $\gamma<1$, the common ion exchange RFB is cheaper, whereas if $\gamma>1$, the saltsplitting RFB is more cost effective. Notably, as the number of electron transfers per molecule increases (higher $n$ ) the salt cost contribution increases linearly for the salt splitting configuration, making common ion exchange RFBs increasingly favorable for multi-electron transfer systems. In most practical examples, the common ion exchange system is cheaper, despite a higher active species molecular weight or cost. This cost analysis does not consider other advantages of ionic modification that can further decrease cost, such as increased redox potential (higher $U$ ). $[8,43]$

$$
\gamma=\frac{\left(M_{m, C I} c_{m, C I}^{\$}-M_{m, \mathrm{SS}} c_{m, \mathrm{SS}}^{\$}\right)}{M_{\text {sol }} c_{\text {sol }}^{\$}\left(r_{\text {sol }, C I}-r_{\text {sol,SS }}\right)+n M_{\text {salt }} c_{\text {salt }}^{\S}}
$$

\section{Conclusion}

Common ion exchange systems couldenable low cost, high energy density NAqRFBs by enhancing active species solubilities and decreasing saltconcentration requirements as compared to their salt splitting alternatives. In this work, amulti-electron, common ion NAqRFB was designedemploying Fe(bpy $)_{3}\left(\mathrm{BF}_{4}\right)_{2}$ and $\mathrm{Fc} 1 \mathrm{~N} 112-\mathrm{BF}_{4}$ as the active species. A systematic electrolyte compatibility study investigated possible interactions between the selected speciesby examining the stability of both active materials, across all relevant oxidation states, both individually and as mixtures. CV, bulk 
electrolysis, and $\mathrm{H}$-cell experiments confirmedthe feasibility of $1 \mathrm{e}^{-}$and $2 \mathrm{e}^{-}$transfer cycling prior to engaging a flow cell study. The $1 \mathrm{e}^{-f l o w}$ cell cycled as predicted from the bulk electrolysisand $\mathrm{H}$-cell experiments. The2e-NAqRFBsuccessfully accessed alldesired redox couples, revealing a unique progression of chargeplateaus. Results from the systematic electrochemical studies explained the complex charging phenomena, and each plateau during the charging process correspondedto specific redox processes observed by CV.A techno-economic analysis highlighted the cost savings afforded by a common ion configurationNAqRFB. Overall, the research described in this paper establishes the cost and performance benefits of common ion exchange NAqRFBs and demonstrates the first $2 e^{-}$full flow NAqRFB. Although the stability, efficiency, energy density, and cost of the demonstration chemistry and performance of the flow cell selected for this study are insufficient for grid implementation, the developed methodologies can extend to other promising redox chemistries, including all-organic, all-MCC, and mixed MCC/organic systems. Couplingtailored posolyte and negolyteactive specieswith the concept of common ion exchange, multi-electron transfer, and asymmetric compatibility, will lead to the development ofNAqRFBsthat approach the DOE price target.

\section{Acknowledgements}

This work was funded by the Joint Center for Energy Storage Research (JCESR), an Energy Innovation Hub funded by the United States Department of Energy, Office of Science, Basic Energy Sciences. Sydney Laramie and Jarrod Milshtein thank the National Science Foundation Graduate Research Fellowship Program for additional financial support (DGE 1256260). We would also like to thank the JCESR Flow Chemistry Sprint team for their continued input and support, including: Dr. Xiaoliang Wei, Dr. Rama Vemuri, Dr. Wentao Duan, Dr. Robert Darling, Dr. Kevin Gallagher, Dr. Kyle Smith, and Rylan Dmello. We especially thankDr. Krista Hawthorne for her early contributions to this project and acknowledge synthesis support from Thomas Carney. We further thank the StranoResearch Group at MIT for sharing their UV-Vis instrumentation and the Brushett Group at MIT and Thompson Group at the University of Michigan for offering constructive feedback throughout the duration of the project. 


\section{References}

[1] P. Denholm, E. Ela, B. Kirby, M. Milligan, The role of energy storage with renewable electricity generation: NREL/TP-6A2-47187, 2010.

[2] B. Dunn, H. Kamath, J.M. Tarascon, Electrical energy storage for the grid: A battery of choices, Science.334 (2011) 928-935.

[3] W. Wang, Q. Luo, B. Li, X. Wei, L. Li, Z. Yang, Recent progress in redox flow battery research and development, Adv. Funct. Mater. 23 (2013) 970-986.

[4] D. Rastler, Market driven distributed energy storage requirements for load management applications, Palo Alto, CA, 2007.

[5] R.M. Darling, K.G. Gallagher, J.A. Kowalski, S. Ha, F.R. Brushett, Pathways to low-cost electrochemical energy storage: a comparison of aqueous and nonaqueous flow batteries, Energy Environ. Sci. 7 (2014) 3459-3477.

[6] V. Viswanathan, A. Crawford, D. Stephenson, S. Kim, W. Wang, B. Li, et al., Cost and performance model for redox flow batteries, J. Power Sources. 247 (2014) 1040-1051.

[7] K. Xu, Nonaqueous liquid electrolytes for lithium-based rechargeable batteries, Chem. Rev. 104 (2004) 4303-417.

[8] X. Wei, L. Cosimbescu, W. Xu, J.Z. Hu, M. Vijayakumar, J. Feng, et al., Towards high-performance nonaqueous redox flow electrolyte via ionic modification of active species, Adv. Energy Mater. 5 (2014) 1400678.

[9] P.J. Cabrera, X. Yang, J.A. Suttil, R.E.M. Brooner, L.T. Thompson, M.S. Sanford, Evaluation of tris-bipyridine chromium complexes for flow battery applications: Impact of bipyridine ligand structure on solubility and electrochemistry, Inorg. Chem. 54 (2015) 10214-10223.

[10] J.A. Suttil, J.F. Kucharyson, I.L. Escalante-Garcia, P.J. Cabrera, B.R. James, P.R. F. Savinell, et al., Metal acetylacetonate complexes for high energy density nonaqueous redox flow batteries, J. Mater. Chem. A. 3 (2015) 7929-7938.

[11] J. Huang, L. Su, J.A. Kowalski, J.L. Barton, M. Ferrandon, A.K. Burrell, et al., A subtractive approach to molecular engineering of dimethoxybenzene-based redox materials for non-aqueous flow batteries, J. Mater. Chem. A. 3 (2015) 1497114976.

[12] C.S. Sevov, R.E.M. Brooner, E. Chénard, R.S. Assary, J.S. Moore, J. RodríguezLópez, et al., Evolutionary design of low molecular weight organic anolyte materials for applications in nonaqueous redox flow batteries, J. Am. Chem. Soc. 137 (2015) 14465-14472.

[13] B. Scrosati, Lithium rocking chair batteries: An old concept?, J. Electrochem. Soc. 139 (1992) 2776-2781.

[14] L. Gaines, R. Cuenca, Costs of Lithium-Ion Batteries for Vehicles: ANL/ESD-42, 2000.

[15] P.A. Nelson, K.G. Gallagher, I. Bloom, D.W. Dees, Modeling the Performance and Cost of Lithium-Ion Batteries for Electric-Drive Vehicles: ANL-12/55, 2011. 
[16] A.A. Shinkle, T.J. Pomaville, A.E.S. Sleightholme, L.T. Thompson, C.W. Monroe, Solvents and supporting electrolytes for vanadium acetylacetonate flow batteries, J. Power Sources. 248 (2014) 1299-1305.

[17] J.R. Dahn, J. Jiang, L.M. Moshurchak, M.D. Fleischauer, C. Buhrmester, L.J. Krause, High-rate overcharge protection of LiFePO4-based Li-ion cells using the redox shuttle additive 2,5-ditertbutyl-1,4-dimethoxybenzene, J. Electrochem. Soc. 152 (2005) A1283-A1289.

[18] L. Su, R.M. Darling, K.G. Gallagher, W. Xie, J.L. Thelen, A.F. Badel, et al., An investigation of the ionic conductivity and species crossover of lithiated Nafion N117 in nonaqueous electrolytes, J. Electrochem. Soc. 163 (2016) A5253-A5262.

[19] F.R. Brushett, J.T. Vaughey, A.N. Jansen, An all-organic non-aqueous lithium-ion redox flow battery, Adv. Energy Mater. 2 (2012) 1390-1396.

[20] I.L. Escalante-García, J.S. Wainright, L.T. Thompson, R.F. Savinell, Performance of a non-aqueous vanadium acetylacetonate prototype redox flow battery: Examination of separators and capacity decay, J. Electrochem. Soc. 162 (2015) A363-A372.

[21] S.H. Oh, C.W. Lee, D.H. Chun, J.D. Jeon, J. Shim, K.H. Shin, et al., A metal-free and all-organic redox flow battery with polythiophene as the electroactive species, J. Mater. Chem. A. 2 (2014) 19994-19998.

[22] S. Park, J. Shim, J. Yang, K. Shin, C. Jin, B.S. Lee, et al., Electrochemical properties of a non-aqueous redox battery with all-organic redox couples, Electrochem. Commun. 59 (2015) 68-71.

[23] Y. Matsuda, K. Tanaka, M. Okada, U. Takasu, M. Morita, A rechargeable redox battery utilizing ruthenium complexes with non-aqueous organic electrolyte, J. Appl. Electrochem. 18 (1988) 909-914.

[24] M.H. Chakrabarti, R.A.W. Dryfe, E.P.L. Roberts, Evaluation of electrolytes for redox flow battery applications, Electrochim. Acta. 52 (2007) 2189-2195.

[25] P.J. Cabrera, X. Yang, J.A. Suttil, K.L. Hawthorne, R.E.M. Brooner, M.S. Sanford, et al., Complexes containing redox noninnocent ligands for symmetric, multielectron transfer nonaqueous redox flow batteries, J. Phys. Chem. C. 119 (2015) 15882-15889.

[26] N.S. Hudak, L.J. Small, H.D. Pratt, T.M. Anderson, Through-plane conductivities of membranes for nonaqueous redox flow batteries, J. Electrochem. Soc. 162 (2015) A2188-A2194.

[27] M. Park, N. Lee, S. Lee, K.J. Kim, D. Oh, Y. Kim, High-energy redox-flow batteries with hybrid metal foam electrodes, ACS Appl. Mater. Interfaces. 6 (2014) 10729_ 10735.

[28] J. Mun, M. Lee, J. Park, D. Oh, D. Lee, S. Doo, Non-aqueous redox flow batteries with nickel and iron tris (2, 2'-bipyridine) complex electrolyte, Electrochem. SolidState Lett. 15 (2012) A80-A82.

[29] P.J. Cappillino, H.D. Pratt, N.S. Hudak, N.C. Tomson, T.M. Anderson, M.R. Anstey, Application of redox non-innocent ligands to non-aqueous flow battery electrolytes, Adv. Energy Mater. 4 (2014) 1300566. 
[30] J. Park, M. Lee, S. Hwang, D. Lee, D. Oh, Redox flow battery: US2012/0171541 A1, 2012.

[31] L. Cosimbescu, X. Wei, M. Vijayakumar, W. Xu, M.L. Helm, S.D. Burton, et al., Anion-tunable properties and electrochemical performance of functionalized ferrocene compounds, Sci. Rep. 5 (2015) 14117.

[32] J.A. Riddick, W.B. Bunger, Organic Solvents, Wiley-Interscience, 1971.

[33] X. Wei, W. Xu, M. Vijayakumar, L. Cosimbescu, T. Liu, V. Sprenkle, et al., TEMPO-based catholyte for high-energy density nonaqueous redox flow batteries, Adv. Mater. 26 (2014) 7649-7653.

[34] M. Morita, Y. Tanaka, K. Tanaka, Y. Matsuda, T. Matsumura-Inoue, Electrochemical oxidation of ruthenium and iron complexes at rotating ring disk electrode in acetonitrile solution, Chem. Soc. Japan. 61 (1988) 2711-2714.

[35] S.H. Shin, S.H. Yun, S.H. Moon, A review of current developments in nonaqueous redox flow batteries: characterization of their membranes for design perspective, RSC Adv. 3 (2013) 9095-9116.

[36] P. Alotto, M. Guarnieri, F. Moro, Redox flow batteries for the storage of renewable energy: A review, Renew. Sustain. Energy Rev. 29 (2014) 325-335.

[37] N. V Plechkova, K.R. Seddon, Applications of ionic liquids in the chemical industry, Chem. Soc. Rev. 37 (2008) 123-150.

[38] J. Huang, L. Cheng, R.S. Assary, P. Wang, Z. Xue, A.K. Burrell, et al., Liquid catholyte molecules for nonaqueous redox flow batteries, Adv. Energy Mater. 5 (2015) 1401782.

[39] K. Takechi, Y. Kato, Y. Hase, A highly concentrated catholyte based on a solvate ionic liquid for rechargeable flow batteries, Adv. Mater. 27 (2015) 2501-2506.

[40] M.A. Miller, J.S. Wainright, R.F. Savinell, Communication-Iron ionic liquid electrolytes for redox flow battery applications, J. Electrochem. Soc. 163 (2016) A578-A579.

[41] L. Bahadori, M.A. Hashim, N.S.A. Manan, F.S. Mjalli, I.M. AINashef, N.P. Brandon, et al., Investigation of ammonium- and phosphonium-based deep eutectic solvents as electrolytes for a non-aqueous all-vanadium redox cell, J. Electrochem. Soc. 163 (2016) A632-A638.

[42] J. England, C.C. Scarborough, T. Weyhermüller, S. Sproules, K. Wieghardt, Electronic structures of the electron transfer series [M(bpy)3]n, [M(tpy)2]n, and [Fe(t-bpy)3]n (M = Fe, Ru; $\mathrm{n}=3+, 2+, 1+, 0,1-)$ : A Mössbauer spectroscopic and DFT study, Eur. J. Inorg. Chem. 2012 (2012) 4605-4621.

[43] B. Hwang, M.S. Park, K. Kim, Ferrocene and cobaltocene derivatives for nonaqueous redox flow batteries, ChemSusChem. 8 (2015) 310-314.

[44] X. Wei, W. Xu, J. Huang, L. Zhang, E. Walter, C. Lawrence, et al., Radical compatibility with nonaqueous electrolytes and its impact on an all-organic redox flow battery, Angew. Chemie Int. Ed. 54 (2015) 8684-8687. 